\title{
Article
}

\section{Through which medium should science information professionals communicate with the public: television or the internet?}

\author{
Cees M. Koolstra \\ Mark J.W. Bos \\ Ivar E. Vermeulen
}

Science information professionals need to make choices through which media they want to communicate with the public. In reaching large audiences outside the domain of formal diffusion of knowledge, the choice may be between the old medium television and the new medium Internet. It seems that general scientific research is focused more and more on the Internet as a favorite means for information exchange and that the old mass medium television plays only a minor role. But when we look at (1) how the public spends their leisure time on television and the Internet, (2) how effective these media are in transferring information, and (3) how much these media are trusted as reliable sources of information, the old medium television should still be regarded as the number one medium to be used for science communication, although there are some limitations for its use.

\section{Introduction}

In the field of science communication more and more attention seems to be focused on the use of new and interactive media to inform the public about developments in science (e.g., Lederbogen \& Trebbe 2003 ${ }^{1}$; Triunfol $2004^{2}$ ) and to stimulate public engagement in science (e.g., Matzat 2004 ${ }^{3}$; Miah 2005 Nielsen $2005^{5}$ ). Among the new media, the Internet has become the most frequently studied medium. Whereas much attention is focused on the Internet, the attention for the old medium television seems to be declining. Of course, attention needs to be focused on developments in how the new media can be used in communication in general and science communication in particular. However, when science communication professionals stand for the choice which medium to use in their efforts to communicate science, they should take into account how the public uses television and the Internet, and how effective these media are in exchanging information. Based on empirical studies conducted in Europe (and in particular in the Netherlands), the present article argues that the old mass medium television should still be regarded as the most important medium for science communication, because (1) people use television more frequently than the Internet, (2) television is more effective in transferring messages to the public than the Internet, and (3) people have more trust in television than in the Internet as a reliable information source. Of course, as compared to the Internet, the use of the old medium television for science communication has its limitations.

\section{Scientific attention for television and the Internet}

Scientists in general seem to focus more and more attention on the Internet as a favorite means to be used in information processing. A decrease in the scientific attention for studies on television and an increase in studies about the Internet can be illustrated with the use of the often-used and well-known scientific database Web of Science. Table 1 shows that the amount of studies in which television was a topic gradually increased from the sixties to the last decade of the past century. Although the world's first 


\begin{tabular}{|c|c|c|}
\hline Years & Television & Internet \\
\hline $1945-1960$ & 1,205 & 0 \\
\hline $1961-1970$ & 2,448 & 1 \\
\hline $1971-1980$ & 4,015 & 4 \\
\hline $1981-1990$ & 4,956 & 29 \\
\hline $1991-2000$ & 8,118 & 13,208 \\
\hline $2001-2005$ & 4,704 & 21,221 \\
\hline \hline Total & 25,446 & 34,463 \\
\hline
\end{tabular}

Notes. The search included three databases: Science Citation Index Expanded (SCI-Expanded) starting from 1945, Social Sciences Citation Index (SSCI) starting from 1956, and the Arts \& Humanities Citation Index (A\&HCI) starting from 1975. The search was performed on January 18, 2006.

Table 1. Number of studies in which television or the Internet was a topic over the years on the basis of a general search in the Web of Science.

"multiple-site computer network" (ARPAnet) was introduced in 1969, studies in which the Internet played a role were almost non-existent until 1990. In the last decade of the past century however, the Internet became a commercial success and in that same decade the amount of studies on the new medium already surpassed the amount of studies on the old medium television. Data of the present century show that, until now, the number of studies about the Internet is more than four times as high as the number of studies pertaining to television. On one hand, it may be argued that it seems reasonable to pay relatively little attention to the old medium television as compared with the new medium Internet, because through past research we know a lot about television's use and effects and we know relatively little about the effects of using the Internet. Although the Internet has its specific characteristics which makes it a new medium worth studying, other characteristics of the Internet such as the use of texts, pictures and movies are familiar because they can be found in older media such as books and television. In addition, it may be questioned whether the present low attention of scientists for the old medium television as compared to the high attention for the Internet is congruent with the actual situation of how many people in the world have access to these two media, how much time is spent on these media, and the extent to which users see these media as reliable sources of information. An additional question is which medium is most effective in transferring general or scientific information. These questions, in which the old and the new medium are compared, will be answered on the basis of empirical data collected in previous studies about how the public acquires information in non-educational, informal settings. Important to note is that the analysis does not pertain to the question of how television and the Internet are actually used in the field of science communication; the focus here is on the possibilities or potentials that television and the Internet offer to be used for science communication goals. The analysis may therefore help science communication professionals in their choice of which media to use as a means of promoting public awareness, interest, and understanding of science and technology.

\section{The use of television and the Internet by the public}

Television is the first medium young people learn to use when they start processing information. Long before children learn to read, they have become regular and experienced television viewers. The few studies that investigated very young children's attention to television (Huston, Wright, Rice, Kerkman and St. Peters $1990^{6}$; Lemish $1987^{7}$; Lesser $1974^{8}$; Valkenburg and Vroone $2004^{9}$ ) have shown that when children are four to six months old they already show an interest in television programs. It seems that most (young) children like television viewing very much and, based on time-use data, it is the most popular medium among children worldwide. Why is television so popular among children? First, there is a basic and practical reason: A television set is available in almost every household. Second, television viewing is a well-established and primary family activity. Most parents stimulate their children to watch 
television and when parents are busy and have no time to interact with their children, the medium is often used as a cheap and readily available baby sitter. Third, watching television is learned easily. In fact, when compared to older media such as books, and newer media such as computer games and the Internet, the television set can be used without learning. Compared with listening to radio and/or music, an activity which can also be done without learning, television viewing satisfies children's exploring tendencies in a more complete fashion, because the medium provides moving and changing pictures and colors, in addition to sound. Finally, by the time children can understand most television content, they watch TV for the same frequently chosen reasons as adults: to pass the time, to relax, for arousal, for companionship, to learn and to forget (e.g., Rubin $1977^{10} ; 1979^{11}$ ). Most studies on the "uses and gratifications" of the different media have shown that children choose television as the most satisfactory medium for each of the specified functions (e.g., d'Haenens, Kokhuis, and van Summeren 2001 ${ }^{12}$; Rubin $1994^{13}$ ). It may be predicted that television will stay the number one medium for children between the ages of 0 and 12 until a new medium is introduced that incorporates the same attractive characteristics the audio-visual medium has now (see for a more extensive review on science television for children, Koolstra, in press ${ }^{14}$ ).

There are indications that the use of television is somewhat less frequently among high school students between the age of 12 and 18 (e.g., Beentjes, Koolstra, Marseille and van der Voort 2001 ${ }^{15}$ ). Apparently, at that age period television gets competition by the computer used for chatting, surfing on the Internet, e-mailing and playing games. Nevertheless, although television is used somewhat less frequently in that age range, high school students in Europe as well in the United States still spend much more leisure time watching television than using their computer for the Internet (e.g., Beentjes et al., 2001 ${ }^{15}$; Roberts, Foehr and Rideout $2005^{16}$ ). Among adults television is by far the number one medium, and the leisure time spent on television viewing is extremely high among older persons. In contrast, not many older people use computers or the Internet, because they have not grown up to learn to use the new medium.

The conclusion is that, when people grow up, the old medium television will always have a head start because it is so easy to use. On average, children and adults spend much more leisure time watching television than using the Internet. And because there are still generations of people who did not grow up with computers, older persons almost never use the Internet, whereas they are heavy television viewers. As an example, the most recent reliable statistics of television and Internet use in the Netherlands indicate that Dutch people spend on average 12.4 hours per week watching television, whereas only 0.5 hour per week is spent on using the Internet (Broeders and Verhoeven 2005 ${ }^{17}$; Huysmans, de Haan and van den Broek $2004^{18}$ ). Of course, it must be noted that the above mentioned figures about the use of television and Internet pertain to how much time people use these media in their leisure time. When working hours are also included in the statistics, the mean number of hours people use the Internet, in particular e-mail, is much higher than the number of hours the Internet is used exclusively in leisure time.

\section{Public access to television and the Internet around the world}

Although rough estimates that were made a few years ago indicated that the new interactive media are more expensive than older media (e.g., van Dijk $1999^{19}$ ), it may be that nowadays television and Internet use are almost equally expensive. The costs of a cheap television set and computer start both at about 200 Euro. In many countries where Internet access is available, people have to pay comparable prices for access to cable television as for Internet access. However, many more people in the world have access to television than to the Internet. Although reliable and recent worldwide statistics about the penetration of television are not available, the World Communication Report (UNESCO 1999 ${ }^{20}$ ) indicates that people in industrial countries have only three times as much access to television than people in developing countries (respectively, 524 and 145 per 1000 inhabitants have access). In the case of Internet access there is a much stronger digital divide between the rich and poor continents with the biggest difference between North America and Africa with Internet access for respectively $67.4 \%$ and only $1.5 \%$ of the population in 2005 (http://www.internetworldstats.com/stats.htm). 


\section{Information processing through television and the Internet}

Whereas on the one hand television is sometimes criticized for its possible negative effects on school performance (e.g., Dorr 1986 ${ }^{21}$; Koolstra, van der Voort and van der Kamp 199722 ; Pool, Koolstra, and van der Voort $2003^{23}$ ), the other side of the coin is that media comparison studies have shown that the medium should be praised for its positive effects in regard with information processing. The media comparison studies have investigated how well same-content messages are processed and recalled when presented through different media. Although the media comparison studies may be criticized on the basis of questionable ecological validity (Eveland, Seo and Marton 2002 ${ }^{24}$ ) and on the fact that some media characteristics are difficult to compare, researchers have in most studies tried to make the comparison as valid and fair as possible (see for a review, Beentjes and Walma van der Molen $1997^{25}$ ). Most media comparison studies examined through which media fictional or news stories were recalled best. The stories were presented through television (audio-visual), text (print) and/or radio (audio). When general recall was measured through (a) free recall of the story line, (b) cued recall, or (c) picture arrangement, TV groups scored almost always better than radio or print groups (e.g., Beentjes and van der Voort 199126; Greenfield and Beagles-Roos 198827; Walma van der Molen and van der Voort 2000 ${ }^{28}$ ). The superior recall of television information is congruent with Paivio's $\left(1971^{29}\right)$ dual-coding hypothesis, which states that audiovisual information (TV) is stored in memory with two separate but associated codes (visual and verbal), whereas text-only information (print or radio) is stored with a verbal code only. Because the visual and verbal codes can both independently serve as retrieval cues, audiovisual stories are easier remembered than verbal stories.

Until now not many media comparison studies have included the Internet as one of the competing media, but there are indications that information processing through television is also superior to information processing through the Internet (e.g., Dijkstra, Buijtels, and van Raaij $2005^{30}$ ). There is in fact evidence that in most cases learning from the Internet is highly comparable to learning from books (Eveland and Dunwoody $2001^{31}$ ). Internet users and book readers can of course process information in their own tempo, whereas television viewers need to follow the pace set by the producers of a program. The possibility of processing information in one's own tempo is often mentioned as a prerequisite for good learning, because it leaves time to think about difficult information that is processed. Because television does not provide that possibility, the medium may be criticized for its high tempo and shallow way of information processing (e.g., Postman $1985^{32}$; Salomon $1984^{33}$; Winn $1977^{34}$ ). Nevertheless, the outcomes of the media comparison studies suggest that television's disadvantage of a set tempo while processing information is overruled by the advantage of the moving images that are more easily remembered.

It must be noted that some content of the Internet, such as streaming video, is highly comparable to television. However, because most Internet sites consist of text pages and illustrations, the comparison with books applies most. An advantage of the Internet as compared to television is the possibility of interactive communication. Whereas "interactivity" in regard with television is often limited to televoting in the case of specific entertainment programs (e.g., Eurovision song contest and Big Brother), there are more interactivity possibilities for Internet use. Examples are that Internet users can send e-mail messages, engage in chat sessions, change the content of publicly accessible websites (e.g., Wikipedia), and participate in news and discussion groups. Although it may be suggested that most of the activities of Internet users pertain to pleasure (entertainment) or business, the medium also offers possibilities in the context of science communication such as visiting online museums, searching in (scientific) databases and catalogues, participating in distance education, and publishing in electronic format.

An additional strong difference between information processing through television and the Internet is that Internet content is always available whereas television viewers are dependent of which programs are broadcast at what time. In the comparison of information processing through television and the Internet it may be concluded that the possibilities of the Internet are immense and diverse, whereas those of television are limited and uniform. However, because in practice the Internet is predominantly used for surfing, it is not clear whether the rich possibilities of the Internet will get more popular among users than they are now. Until the media convergence has not fully taken place - the availability and quality of watching "television" through the Internet is still limited-it may be assumed that television will be the most popular information source (see also Broeders and Verhoeven $2005^{17}$ ). Once the full convergence 
has taken place, the discussion about which medium is the best or richest information source will change into a discussion about the pros and cons of audiovisual versus textual information.

\section{Trust in television and the Internet as information sources}

With regard to information in general, a recent study conducted in 2005 by one of the big Dutch newspapers (Trouw) showed that $84.2 \%$ of the respondents in the study trusted television as an information source (Meer vertrouwen in media $2005^{35}$ ). In addition, almost half of the respondents $(49 \%)$ chose television as the most important information source, whereas only $7 \%$ chose the Internet as the most important information source. These results are in line with a recent American study (Princeton Survey Research Associates $2005^{36}$ ) indicating that $61 \%$ of the respondents chose television as their main source of information, whereas $11 \%$ chose the Internet. Because the survey was conducted among Internet users, there is no doubt that the high rating of television would have been even higher among a representative sample of the American people.

With regard to scientific information in particular, some studies have investigated whether the public sees television and the Internet as important sources for conveying scientific information. One is a Eurobarometer survey in which exactly this question was asked to people from 15 European countries (Eurobarometer $2001^{37}$ ). Respondents classified the importance of six sources of information about scientific developments on a scale of 1 ("the most important") to 5 ("the least important"). By adding together the high marks (1 and 2), the results indicated that television was judged as a very important medium for scientific information $(60.3 \%)$, whereas the Internet was judged as much less important $(16.7 \%)$. In between television and the Internet the press scored $37.0 \%$, radio $27.3 \%$, school or university $22.3 \%$ and scientific journals $20.1 \%$. It must be noted however that among the youngest respondents and those who were still studying the preference for the Internet was higher $(29.1 \%$ and $33.1 \%$, respectively) than for the complete group.

With regard to the perception of media effects, the most recent Eurobarometer survey $\left(2005^{38}\right)$ showed that $83 \%$ of the Euro citizens believed that television (and radio) reporting on science has a positive effect on society. Questions about the expected effects of the Internet were not asked.

\section{Conclusions and discussion}

It may be concluded that television provides many possibilities to science communication professionals as a medium to be employed. Particularly from the view that for most people processing of general and scientific information takes place in their leisure time, and television is the most frequently used medium, television should be included in the choice of science communication professionals when they aim to promote public awareness, interest, and understanding in science and technology. Of course, when people watch television in their leisure time, it is in most cases not primarily aimed at processing scientific information but predominantly used for entertainment and general information. Nevertheless, especially because many groups in the public may never seek scientific information through any other medium, television provides ample possibilities to get people acquainted with scientific content. A recent analysis made by Merzagora, Millington, and Scandola (in press) ${ }^{39}$ has argued that many popular fictional drama series draw on science and technology and they may therefore have a powerful impact on a large audience. Examples of these drama series are CSI (Crime Scene Investigation), Smallpox 2002, E. R. (Emergency Room), and RIS - Delitti Imperfetti (Merzagora et al., in press). The most important conclusion of the authors is that the public perception of science is often implicit and/or unintentional, and because TV drama has the potential to reach a large and undifferentiated audience, this fictional form of television can be seen as a challenging new channel to be used in science communication.

Until now, the Internet is not as popular among the public as television: Much more leisure time is spent on television use than on Internet use. In addition, when people are asked which medium is their most important information source, television is mentioned much more frequently than the Internet. As discussed before, the strong lead of television may disappear in the future, because there is evidence that the younger generations use and value the Internet more than older generations. But our estimation is that a future in which people on average spend more of their leisure time on Internet use than on television 
will take at least 5 more years to come. Until the Internet is technically developed to provide a wide choice in high quality movies and live broadcasts of news and entertainment, television will be the number one medium for most of the public. This does not mean, however, that the Internet should be neglected in science communication. People who intentionally search for scientific information use the Internet frequently and the medium offers many possibilities to find a broad scope of background scientific information. A big advantage of the Internet is that looking for information can be done at any time of the day. But a disadvantage, also recognized by Internet users, is that much of the information on the Internet is of dubious quality and reliability (e.g., Trumbo, Sprecker, Dumlao, Yun and Duke $2001^{40}$ ). And, as stated before, the Internet is not yet established as an important medium in developing countries, which decreases the possibility to use the Internet in worldwide science communication efforts.

A limitation of the present study is that most of the evidence presented here is based on findings from European studies. It may be suggested that Europe is somewhat behind in developments in media use as compared to the United States. It may be true that new media like the Internet will displace older media such as television sooner in the United States than in Europe. The few American studies on media use that were reported here, however, indicate that nowadays among Americans too television is still the most frequently used leisure time medium. Another limitation of the present study is that it focuses on two of the most popular media in the context of science communication. There are of course various small-scale methods through which science can be communicated in an effective and interactive way. Examples are science exhibits, public debates about science, and science centers. The advantage of these means of exchanging scientific information is that they are more interactive and more personal than television and the Internet. They will therefore be also more effective than the old media, although it must be noted that until now studies in which the effectiveness of the different methods is compared are scarce. The biggest differences between the small- and large-scale methods used in science communication are the size and the level of involvement of the audiences that can be reached. Smallscale methods such as science exhibitions attract small audiences of people who are interested in science from the very start. Mass-media methods such as the Internet and television have much bigger audiences of which many people may have no interest in science at all. The present study indicates that television in particular is an important medium to initiate and stimulate the interest in science, because it may expose people to scientific information in an unintentional way. Once television gets people get interested in science, they may explore other means of information exchange such as the Internet and science centers and exhibitions.

\section{Notes and references}

${ }^{1}$ U. Lederbogen and J. Trebbe (2003). Promoting science on the Web. Public relations for scientific organizations: Results of a content analysis. Science Communication, 24(3), 333-352. <http://dx.doi.org/10.1177/1075547002250299>.

${ }^{2}$ M.L. Triunfol (2004). Dynamics of list-server discussion on genetically modified foods. Public Understanding of Science, 13(2), 155-175. <http://dx.doi.org/10.1177/0963662504044110>.

3 U. Matzat (2004). Academic communication and Internet Discussion Groups: Transformation or creation of social contacts? Social Networks, 26(3), 221-255. <http://dx.doi.org/10.1016/j.socnet.2004.04.001>.

4 A. Miah (2005). Genetics, cyberspace, and bioethics: Why not a public engagement with ethics? Public Understanding of Science, 14(4), 409-421. <http://dx.doi.org/10.1177/0963662505056616>.

5 K.H. Nielsen (2005). Between understanding and appreciation: Current science communication in Denmark. Journal of Science Communication, 4(4), 1-9. (Retrieved February 12, 2006 from: http://jcom.sissa.it). <http://jcom.sissa.it/archive/04/04/A040402/>

${ }^{6}$ A.C. Huston, J.C. Wright, M.L. Rice, D. Kerkman and M. St. Peters (1990). The development of television viewing patterns in early childhood: A longitudinal investigation. Developmental Psychology, 26, 409-420.

7 D. Lemish (1987). Viewers in diapers: The early development of television viewing. In T.R. Lindlof (Ed.), Natural audiences: Qualitative research of media uses and effects (pp. 33-57). Norwood, NJ: Ablex.

8 G. Lesser (1974). Children and television: Lessons from Sesame Street. New York: Vintage.

9 P.M. Valkenburg and M. Vroone (2004). Developmental changes in infants' and toddlers' attention to television entertainment. Communication Research, 31(1), 288-311 <http://dx.doi.org/10.1177/0093650204263435>.

10 A.M. Rubin (1977). Television usage, attitudes and viewing behaviors of children and adolescents. Journal of Broadcasting, 21(3), 355-369.

11 A.M. Rubin (1979). Television use by children and adolescents. Human Communication research, 5(2), 109-120. <http://dx.doi.org/10.1111/j.1468-2958.1979.tb00626.x>. 
${ }^{12}$ L. d'Haenens, M. Kokhuis and van Summeren (2001). Kijken of surfen? Mediagebruik van kinderen en adolescenten [Watching or surfing? Media use of children and adolescents]. Leuven/Leusden: Acco.

${ }^{13}$ A.M. Rubin (1994). Media uses and effects: A uses-and-gratifications perspective. In J. Bryant and D. Zillmann (Eds.), Media effects: Advances in theory and research (pp. 417-436). Hillsdale, NJ: Lawrence Erlbaum Associates.

${ }^{14}$ C.M. Koolstra (in press). Science television for children. In J.T.J.M. Willems and W. Goepfert (Eds.), Television and science communication. Amsterdam: VU Press.

${ }^{15}$ J.W.J. Beentjes, C.M. Koolstra, N. Marseille and T.H.A. van der Voort (2001). Children's use of different media: For how long and why? In S. Livingstone \& M. Bovill (Eds.), Children and their changing media environment (pp. 85-111). Los Angeles, CA: Erlbaum.

${ }^{16}$ D.F. Roberts, U.G. Foehr and V. Rideout (2005). Generation M: Media in the lives of $8-18$ year-olds. Menlo Park, CA: Kaiser Family Foundation.

17 D. Broeders and I. Verhoeven (2005). Kiezen uit overvloed: Sociaal-culturele ontwikkelingen in vraag en aanbod in het medialandschap [Social-cultural developments in supply and demand in the media landscape]. In W. van de Donk, D. Broeders \& F. Hoefnagel (Eds.), Trends in het medialandschap: Vier verkenningen, WRR Verkenningen nr. 7 (pp. 67-121). Amsterdam: Amsterdam University Press.

${ }^{18}$ F. Huysmans, J. de Haan and A. van den Broek (2004). Achter de schermen: Een kwart eeuw lezen, luisteren, kijken en internetten [Behind the screens: A quarter of a century reading, listening, watching and using the Internet]. Den Haag: Sociaal Cultureel Planbureau.

${ }^{19}$ J.A.G.M. van Dijk (1999). Network society, social aspects of new media. London: Sage.

20 UNESCO (1999). World Communication Report 1999-2000. Retrieved February 19, 2006 from: <http://www.unesco.org/webworld/wcir/en/report.html>.

${ }^{21}$ A. Dorr (1986). Television and children: A special medium for a special audience. Beverly Hills: Sage.

${ }^{22}$ C.M. Koolstra, T.H.A. van der Voort and L.J.Th. van der Kamp (1997). Television's impact on children's reading comprehension and decoding skills: A three-year panel study. Reading Research Quarterly, 32, 128-152.

${ }^{23}$ M.M. Pool, C.M. Koolstra and T.H.A. van der Voort (2003). The impact of background radio or television on high school students' homework performance. Journal of Communication, 53, 74-87. <http://dx.doi.org/10.1111/j.1460-2466.2003.tb03006.x>

${ }^{24}$ W.P. Eveland, M. Seo and K. Marton (2002). Learning from the news in campaign 2000: An experimental comparison of TV news, newspapers, and online news. Media Psychology, 4(4), 353-378.

<http://dx.doi.org/10.1207/S1532785XMEP0404_03>

${ }^{25}$ J.W.J. Beentjes and J.H. Walma van der Molen (1997). The impact of television, radio and print on children's recall and creative imagination: A review of media comparison research. Trends in Communication, 2, 31-49.

${ }^{26}$ J.W.J. Beentjes and T.H.A. van der Voort (1991). Children's written accounts of televised and printed stories. Educational Technology Research and Development, 39(3), 15-26. <http://dx.doi.org/10.1007/BF02296435>

${ }^{27}$ P.M. Greenfield and J. Beagles-Roos (1988). Television vs. radio: Their cognitive impact on different socioeconomic and ethnic groups. Journal of Communication, 38(2), 71-92. <http://dx.doi.org/10.1111/j.1460-2466.1988.tb02048.x>

28 J.H. Walma van der Molen and T.H.A. van der Voort (2000). The impact of television, print and audio on children's recall of the news: A study of three alternative explanations for the dual-coding hypothesis. Human Communication Research 26, 3-26. <http://www.blackwell-synergy.com/doi/abs/10.1111/j.1468-2958.2000.tb00747.x>

${ }^{29}$ A. Paivio (1971). Imagery and verbal processes. New York: Holt.

${ }^{30}$ M. Dijkstra, H.E.J.J.M. Buijtels and W.F. van Raaij (2005). Separate and joint effects of medium type on consumer responses: A comparison of television, print, and the Internet. Journal of Business Research, 58(3), 377-386.

<http://ideas.repec.org/a/eee/jbrese/v58y2005i3p377-386.html>

${ }^{31}$ W.P. Eveland and S. Dunwoody (2001). User control and structural isomorphism or disorientation and cognitive load? Learning from the Web versus print. Communication Research, 28(1), 48-78. <http://crx.sagepub.com/cgi/content/abstract/28/1/48>.

${ }^{32}$ N. Postman (1985). Amusing ourselves to death. New York: Viking.

${ }^{33}$ G. Salomon (1984). Television is "easy" and print is "tough": The differential investment of mental effort as a function of perceptions and attributions. Journal of Educational Psychology, 76, 647-658. <http://content.apa.org/journals/edu/76/4/647>.

${ }^{34}$ M. Winn (1977). The plug-in drug. New York: Viking.

${ }^{35}$ Meer vertrouwen in media dan in politiek [More trust in the media than in politics]. (2005, February 3). Trouw, p. 2.

${ }^{36}$ Princeton Survey Research Associates (2005). Leap of faith: Using the internet despite the dangers. Results of a national survey of internet users for Consumer Reports WebWatch. Retrieved November 11, 2005, from:

<http://www.consumerwebwatch.org/dynamic/web-credibility-reports-princeton.cfm>

37 Eurobarometer (2001). Europeans, science and technology. Eurobarometer 55.2. Directorate-General for Press and communication, Public Opinion Sector.

38 Eurobarometer (2005). Social values, science and technology. Eurobarometer 63.1. Directorate-General for Press and communication, Public Opinion Sector.

${ }^{39}$ M. Merzagora, A. Millington and M. Scandola (in press). Science in drama: Science as a part of the story. In J.T.J.M. Willems and W. Goepfert (Eds.), Television and science communication. Amsterdam: VU Press.

${ }^{40}$ C. Trumbo, K. Sprecker, R. Dumlao, G. Yun and S. Duke (2001). Use of e-mail and the Web by science writers. Science Communication, 22(4), 347-378. <http://scx.sagepub.com/cgi/content/abstract/22/4/347> 


\section{Authors}

Cees M. Koolstra is associate professor at the Department of Science Communication (Faculty of Earth and Life Sciences) at the Vrije Universiteit Amsterdam (the Netherlands). He is also associate professor and research manager at the Department of Communication Science (Faculty of Social Sciences) at the same university. His research focuses on science communication through the media and on effects of media use. E-mail: cm.koolstra@fsw.vu.nl.

Mark J. W. Bos is PhD student at the Department of Science Communication (Faculty of Earth and Life Sciences) at the Vrije Universiteit Amsterdam. His $\mathrm{PhD}$ project pertains to how new scientific developments (i.e. ecogenomics) are communicated to and perceived by the public. E-mail: mark.bos@falw.vu.nl.

Ivar E. Vermeulen is assistant professor at the Department of Communication Science (Faculty of Social Sciences) at the Vrije Universiteit Amsterdam. His research focuses on the relations between media content, use and effects. E-mail: IE.Vermeulen@fsw.vu.nl. 